\section{HSE}

Historia Social y de la Educación

Social and Education History
Hipatia Press

www.hipatiapress.com

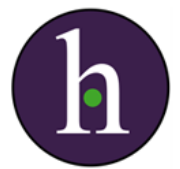

Instructions for authors, subscriptions and further details:

http://hse.hipatiapress.com

\title{
The McMillan Sisters, The Roots of the Open-Nursery, and Breaking the Cycle of Poverty
}

Betty Liebovich ${ }^{1}$

1) Goldsmith. University of London (United Kingdom)

Date of publication: February $23^{\text {rd }}, 2018$

Edition period: February 2018 - June 2018

To cite this article: Liebovich, B. (2018). The MacMillan sisters, the roots of the open-nursery, and breaking the cycle of poverty. Social and Education History, 7(1), 78-96. doi:10.17583/hse.2018.2925

To link this article: http://dx.doi.org/10.17583/hse.2018.2925

\section{PLEASE SCROLL DOWN FOR ARTICLE}

The terms and conditions of use are related to the Open Journal System and to Creative Commons Attribution License (CC-BY). 


\section{The McMillan Sisters, the Roots of the Open-Nursery, and Breaking the Cycle of Poverty}

Betty Liebovich

Goldsmith. University of London (United

Kingdom)

\section{Abstract}

This article explores the impetus and motivation for the McMillan sisters, Christian Socialists committed to creating change for the working class in England, to create an innovative and enduring ideal of nursery education through the open-air nursery. Influenced by their membership in the Fabian Society and the Independent Labour Party, they created health and dental clinics for people living in deprivation in Yorkshire and East and South East London, England, campaigned for the 1906 Provision of School Meals Act, and created night camps for deprived children in Deptford in 1908.The night camps were the inspiration for educating young children and in March 1914, the open-air nursery opened for the youngest children living in the tenements of Deptford. Using archival methods, the conclusion is reached that the McMillan sisters, and Margaret specifically, worked tirelessly to create social change through the open-air nursery serving the deprived surrounding community. By modelling good practice, both educationally and hygienically, they hoped to make a difference in the lives of families stuck in a cycle of poverty. The enduring work and ideas formulated in this nursery have informed many initiatives focused upon reducing social disadvantage, to include the UK framework 'Every Child Matters'.

Key words: open-air nursery, young children, deprivation, social reform 


\section{Las hermanas McMillan, los Orígenes de la Guardería al Aire Libre y la Ruptura del Ciclo de Pobreza}

Betty Liebovich

Goldsmith. University of London (United

Kingdom)

\section{Abstract}

Este artículo explora el ímpetu y la motivación de las hermanas McMillan, socialistas cristianas comprometidas con el cambio para la clase trabajadora en Inglaterra, para crear un ideal innovador y perdurable de educación infantil a través de la guardería al aire libre. Influenciadas por su vinculación a la Sociedad Fabiana y al Partido Laborista Independiente, crearon clínicas de salud y odontológicas para personas en situaciones de pobreza en Yorkshire y en Londres; hicieron campaña para la Ley de Comidas Escolares de 1906 y crearon campamentos para menores desfavorecidos. Los campamentos fueron la inspiración para educar a niños pequeños y en 1914 se abrió la guardería al aire libre para menores que vivían en apartamentos de alquiler en Deptford. Utilizando métodos de archivo, se concluye que las hermanas McMillan, y específicamente Margaret, trabajaron incansablemente para generar un cambio social a través de la guardería al aire libre, la cual prestaba servicios a la comunidad desfavorecida de su entorno. Al modelar buenas prácticas, tanto desde el punto de vista educativo como higiénico, esperaban marcar una diferencia en las vidas de las familias atrapadas en ciclos de pobreza. El trabajo duradero y las ideas formuladas en esta guardería han inspirado a muchas iniciativas centradas en la reducción de las desigualdades sociales, como por ejemplo la iniciativa 'Every Child Matters' de Reino Unido.

Key words: guardería al aire libre, infancia, desigualdad, reforma social 


\section{T argaret and Rachel were born in Westchester County, New York, USA and lived there until they were 5 and 6 years old. Margaret describes their childhood:}

It is a very happy life. Our parents are modern and American in their ideas of how we shall be brought up. They impose no needless restrictions on us, and do not overwhelm us with the Atlas of unreasoning and almighty authority — and yet we are not left to the mercy of impulse and riot of selfish instinct. (McMillan, 1927, p.10)

However, their lives were suddenly changed by the death of their father and youngest sister, Elizabeth. Their mother, distraught and grief-stricken, made the decision to return to her family in Scotland with Margaret who was five years old and Rachel who was six years old in order to have support in raising her two daughters and giving them a better life than she could on her own. Margaret writes: "So, in September [1865], we three went on board the good ship City of Boston, for Liverpool, en route for Inverness" (McMillan, 1927, p.12).

During this time, Margaret lost her hearing and did not regain it until she was about 14 years old. Rachel and Margaret were well educated while living in Scotland, but Margaret found her grandparents to be far too authoritarian, imposing what she considered needless restrictions on her and Rachel, and left her home in Scotland at the age of 18 to study Psychology and Physiology, followed by Languages and Music in Germany. She then became a governess for various wealthy families in Germany.

Eventually, Margaret relocated to London. In 1887, Rachel, while still in Scotland, was introduced to Christian socialism and read articles by William Morris and William Thomas Stead and after July 1888 joined her sister in London. Here she converted Margaret to socialism and they together attended political meetings, where they met William Morris, H. M. Hyndman, Peter Kropotkin, William Stead and Ben Tillett. In 1889, Rachel and Margaret supported the workers during the London Dock Strike, to include marching and demonstrating at Parliament. Margaret's activities included membership of the Fabian Society, teaching young women in the East End, public speaking and investigative journalism (Steedman, 1990). In 1892 they moved to Bradford, West Yorkshire where they joined the Fabian 
Society, the Labour Church, the Social Democratic Federation and the Independent Labour Party (ILP). Margaret was elected to the Bradford School Board as a representative of the ILP in November 1894, swiftly becoming a remarkably active social reformer with a keen interest in child welfare (McMillan, 1927). She was re-elected to the school board in 1900, but in 1902 a new Education Bill became law, resulting in the abolition of the School Boards, giving control and management of primary schools to the District and County Councils- to which women could not be elected (Steedman, 1990, p.49). Disappointed, but determined, Margaret joined her sister, a travelling teacher of health and hygiene, in Bromley, London.

In 1906, Margaret and Rachel campaigned for the compulsory medical inspection of school children (McMillan, 1927, p. 118) which was subsequently realised in the Education (Administrative Procedures) Bill of 1907. They opened a medical and dental clinic in Deptford, London, considered a suitably 'needy' area of London in which Margaret had managed a group of primary schools and was familiar with the community and their needs. Once the sisters secured housing on Evelyn Street in Deptford, they opened night camps for girls in 1908, where local girls from ages 6-14 had a hot meal in the evening, washing facilities for themselves and their clothes and a cot on which to sleep outdoors, maximising on the fresh air and nutritious food.

Deptford was one of the most built-up areas of London and one of the poorest. In 1911 the population for the Borough of Deptford numbered 109,000 . There was a density of 72 persons per acre in Deptford, compared to Lewisham with 25 and Greenwich with 26 per acre. In the East Ward where the McMillans would do much of their work, the density was 131 people per acre. (McMillan Legacy Group, 1999, p. 12)

The McMillan sisters took an unorthodox perspective upon the issue of breaking the cycle of poverty, and, rather than enforcing ideals perpetuated by the government to leave those living in deprivation to be supported by the state, proposed that all young children, given that they were developmentally unready to be economically active, were automatically 'deserving poor', that is, entitled to support to provide opportunities they would not otherwise have 
access. With this in mind, young children soon became a focus for the McMillan sisters in order to break the cycle of deprivation and poor hygiene in which they were being raised.

The plight of the youngest children became even more imbedded in her [Margaret McMillan's] developing philosophy when, in 1905, Article 53 of the Education Code stated that under-fives should be removed from the infants departments of elementary schools. This caused a dramatic drop in the number of three to five year olds in schools. The dozens of toddlers the McMillans encountered playing in the gutters of Deptford after 1905 were a direct result of this Education Code directive. The sudden lack of educational provision for under-fives is likely to have influenced Margaret McMillan to move towards the development of the 'Baby Camp' and later the 'Nursery School'. (McMillan Legacy Group, 1999, p.13)

In keeping with the Fabian Society's ideals for educating young children (Pease, 1916, p. 89), and believing children require fresh air, nutritious food and good hygiene, Margaret and Rachel created the nursery to support the young children and families living in squalor and deprivation in Deptford through education, nutrition and health and hygiene. In light of these convictions:

Margaret McMillan was keen to introduce and utilise new educational methods for the teaching of the pre-school children who attended the Baby Camp. She had made extensive trips abroad to observe the experimental work of other educationalists and had extensively studies the work and writings of Fredrich Froebel and Edouard Seguin among others. She drew upon some of their ideas and introduced them to the camp. She had come to believe that children should be nurtured and encouraged with love and kindness to think for themselves and to learn through the freedom of play. (McMillan Legacy Group, 1999, p. 28) 


\section{HSE - Social and Education History, 7(1) 83}

\section{Methodology}

This is a case study of one particular nursery school and their founders. The McMillan's nursery is considered the first open-air nursery in England and their pedagogy was ground breaking at the time. In order to understand the roots of the Rachel McMillan Nursery and the impetus for the McMillan sisters to establish this revolutionary ideal for social change in the impoverished area of Deptford, archival material was sought that offers artefacts about the sisters, their networks, the nursery, families and children who took advantage of the nursery's services and any other information that would assist in painting a picture of who these women were and what they actually accomplished. According to Ventresca and Mohr (2001) "archival methods are those that involve the study of historical documents; that is, documents created at some point in the relatively distant past, providing us access that we might not otherwise have to the organizations, individuals, and events of that earlier time" (p. 2). Studying these historical documents offered a glimpse not only into the nursery and the provision offered, but into the lives of the McMillan sisters and some of the issues they encountered in creating social change.

The first port of call for archival materials was the Dreadnought Library at Greenwich University which housed the McMillan archives. Artefacts included most of the paperwork collected through the history of the Rachel McMillan Nursery until the mid-1950's, personal and official letters written to Margaret McMillan, Margaret's CBE from King George V, and personal correspondence with well-known and wealthy contacts made through the Fabian Society among other social networks. The second port of call was the archives of the London School of Economics in which all of the historical documents of the Nursery School Association are kept. Margaret was the first president of this association and was eventually forced to step down from the position because of her unwavering convictions about early years provision that were opposed by other powerful members of the association. The LSE archives offered written correspondence that follows the trail of dissention among the members of the NSA and Margaret's eventual resignation as president. These documents offered insight into Margaret's convictions about educating teachers of young children and her steadfast belief that young children deserve only the best and brightest practitioners as 
well as focusing on the whole child, not just their intellectual development. The third port of call was to access and read as much of Margret's publications as possible, to gain an understanding of her passion for supporting young children and their families and the need for intelligent, well- educated teachers for the young children living in deprivation.

According to Villaverde, Helyar, and Kincheloe (2006) "asking questions about history, particularly about the relationship between people, events, and the times that create history (p. 2)" is at the heart of historiography. This research was a result of enquiry into the roots of the open-air nursery which, it turns out, are based in the Rachel McMillan Nursery. Further, the McMillan sisters were themselves an integral part of educational history beyond the nursery, to include the School Meals Act (1906) and school medical inspections (1907) for all children in England. This investigation attempted to focus on their impetus for actively pursuing social change for people living in poverty in Deptford and why they felt that education was their best course of action. This historical research about the McMillan sisters is underpinned "By prioritizing being and existence and using it to conduct historical studies, events and people of the past take on a larger human quality" (Villaverde, et al, 2006, p.5). As the McMillans were selfproclaimed and active Christian Socialists, historical and archival research allowed a focus "on human agency, the ability to extract the power of individual stories and collective endeavours in changing culture and society" (Villaverde, et al., 2006, p.11). This historical method permitted active participation in the past through an in-depth search through archival material and reading literature written by Margaret herself. Ultimately, connections could be made between thoughts and being, ideas, and events. This investigation attempts to extract the social and political spirit through textual analysis and questions of past practices.

\section{Early 20th Century Nursery Education in England}

The founding of the Rachel McMillan Nursery in March 1914 coincided with the impending war, providing opportunities for the children of the women working in the munitions factories in neighbouring Woolwich which funded the nursery's existence during WWI. The McMillan sisters struggled to sustain the nursery, training and retaining a qualified staff in the face of 
zeppelin air raids, providing a safe space for the children whose homes were being destroyed by fire raids and families poisoned by gas from the bombs. The nursery survived the First World War and set a precedent for early years education and teacher education that influences the education and care of young children and future teachers more than 100 years later.

In 1893, following the growth of socialism, which was a result of the 1867 Reform Act and the 1870 Education Act, the Independent Labour Party was formed. Socialism broadly stood for the 'social ownership of the means of production and exchange and saw the winning of political power by the working class as the essential means to achieving this end'. This resulted in 'a vision of society in which labour would be pleasurable and education would be the right of all' (Simon, 1965, p. 18). Education and welfare were then central to Margaret's socialist philosophy. Margaret was a prominent member of the Independent Labour Party and the Fabian Society. She and Rachel initially identified themselves as Christian Socialists (a group of Christians tackling what they considered were the reasonable grievances of the working class). They took up the cause of the working class and their children in Deptford, becoming founders of innovative nursery education and care for the children of the working class in England. The pioneering nurseries [in England] were philanthropic in spirit, providing social and medical welfare to underprivileged children in working class districts (Franklin, 2009, p.11). In 1914, a nursery school "conformed to the prevailing ideal that nursery and infant provision were separate stages of education, with separate building types" (Franklin, 2009, p.52). Embracing this ethos, the McMillan's open-air nursery, which became a model for future nursery schools, was built on The Stoawage, an area once used to dump goods from the neighbouring shipping yards. The open-nursery was situated in the middle of the tenement community in which the families using the nursery lived, offering children a large garden in which to learn, clean clothes to wear while in the nursery and nutritious meals three times a day.

The McMillan's nursery, the most influential English model for open-air education started as a school unsupported by the London County Council (LCC). Eventually, the LCC in 1920 grant-aided and directly funded the extension of the Rachel McMillan school, London Borough of Greenwich when funding for other nurseries separate from infant schools was suspended 
(Franklin, 2009, p. 52). By the 1930s it was the largest nursery school in England, with 272 pupils. Margaret McMillan had established a wellfounded nursery school with consistently high numbers of children enrolled and teachers being educated, proving, in a time when government funding was scarce, that her approach to early years education was valued and respected.

The nursery was designed with shelters bordering a large, well-developed garden, where children spent the majority of their time exploring, playing and developing in a community with little or no green spaces and cramped, overcrowded housing.

Initially described as a 'camp school' [because primary school aged children used to spend the night there], it comprised of a number of self-contained timber and asbestos-sheet shelters (said to be designed by Rachel) standing in a garden... The south walls were highly glazed with folding doors. Shelters built in the later 1920s were largely glazed and described by Margaret as 'like a greenhouse'. The shelters each accommodated 35-50 children and were self-contained, having separate cloakrooms, bathrooms and sanitation. (Franklin, 2009, p. 75)

An important aspect of the nursery was to educate future teachers of young children. Margaret recognised the importance of well trained teachers as she felt that children were being 'cheated' by being subjected to inadequately trained teachers. In her opinion 2 years with 2 teaching practices was inadequate and believed that the job of educating young children could not be achieved without extensive training that took three years. Margaret stated emphatically that teachers of young children must have "a finer perception and a wider training and outlook than is needed by any other kind of teacher" (McMillan, 1919, p. 27). Young women from all over the UK and the world enrolled in the teacher education programme offered at the Rachel McMillan Nursery (re-named in 1921 for the deceased sister who co-founded the nursery). By 1921, the school was recognised by the Board of Education as a Training Centre for certified teachers, although Margaret and Rachel had been training teachers since the nursery's inception in March 1914. 


\section{Breaking the Cycle of Poverty}

Due to the conscription and casualties of WWI, married women and widowed women were recruited to work in the munitions factories in neighbouring Woolwich (the home of the Artillery since the 17th century and which employed 80,000 workers during the war). Additionally, women found employment in transport (the rail lines and driving buses and trams), nursing, factories, the Women's Royal Air Force (where they worked on planes as mechanics), on farms in the Women's Land Army and in shipyards. These opportunities allowed women living in the squalor of Deptford an opportunity to break their cycle of poverty through earning a liveable wage and to develop skills that could lead to higher paying work after the war.

Margaret's mission for the nursery was to offer children living in poverty and deprivation an opportunity to flourish and learn in a supportive and healthy environment. A woman who had been a child attending the nursery in 1917-1919 wrote: "She [Margaret] was so proud, so full of love, for her children and her school. She did so want us to be something useful in life and do great things" (Lob,1961). Children were offered opportunities to visit the community with Margaret. Lob (1961) wrote: "The many outings Miss McMillan took us on, by herself, visits to the "Old Vic", Tower of London, British Museum, Albert Hall..”.

The nursery offered a safe and nurturing environment for children to spend their day while mothers worked in the surrounding community. Rosie Cawte, who attended the nursery from 1914-1917 says:

I was taken to the Nursery School before I was two years old. My father was a soldier in France in 1914, my mother was working in munitions, so one can imagine what a relief it was to her to know that I was being so well looked after. (Puddephat, 1977, p. 5)

Margret was dedicated to the children who attended her nursery and the feeling was mutual. Rosie Brain, who attended the nursery in the 1920s remembers: 
I can see her now, a determined figure nearly always clad in black, with a head of lovely silver hair, not always very tidy. I often did it up for her and saw to it that she had no slip showing. (Brain, 1961)

Margaret focused on the children developing speech patterns that were considered respectable in broader society and to help them break the habits of using colloquial language in order to gain respect and support the children in gaining access to better work and careers in adulthood. Brain (1961) goes describes the expectations Margaret had of the children in the nursery saying "She was most particular in the way we spoke, and was also a great lover of Shakespeare, amongst other poets".

Brain (1961) reflects on the impact Margaret had on her development while attending the nursery:

I can see Miss McMillan's face now, she was so proud so grateful of her children - and so she deserved to be. I am always so grateful for having been fortunate to have shared, what I think, the most important years of my live, with a truly wonderful lady.

Supporting children and families with little or no resources was at the heart of the Nursery provision and dear to Margaret's vision for helping the children break the cycle of poverty into which they had been born.

\section{The Nursery}

The McMillan sisters recognised that many poor children in England were lacking both care and education in their most formative years. Besides providing care and education, the program was designed to identify health problems before they entered into formal schooling. The sisters focused on education via a child's 'sense of wonder' and believed teachers must know what attracts children and engages their attention. They also wished to help parents learn how to interact in a positive manner with their children.

With the dawn of WWI and women entering the workforce, earning wages similar to that of men, there was a need for nursery provision to allow these women to place their children in a safe, enriching environment while they worked. 


\section{HSE - Social and Education History, 7(1) 89}

[With a]....boom in munitions...money poured into the district. The women were absent all day in the factories, the camps became full and the Ministry of Labour gave a grant of sevenpence a day for minding each child under five. (Cresswell, 1948, p. 143)

The nursery routine was organised to offer children an engaging experience of learning and development mostly outdoors with shelters designed for indoor learning should the children prefer to be out of the elements. The doors of the nursery opened at 7:30 when the mothers could drop off their children on their way to the factories or whatever other work in which they were employed. Most children arrived between 8:00 and 9:00. Children were immediately bathed and dressed in clean clothing provided by the school which allowed the children freedom of movement to be active learners. A breakfast of porridge and milk was provided and children were allowed to serve themselves, sitting at child-sized tables in the outdoors and were expected to clean up after themselves when finished. Mornings were spent doing hand work or playing the garden (or in the shelters in poor weather) (McMillan, 1917, pp. 84-85). The outdoors and freedom of expression were an integral part of all daily activities. The large garden was the centre of the nursery and had many varieties of vegetation, to include trees in which the children could climb. There were vegetable gardens that provided produce to make children's dinner and tea, chickens for eggs and an assortment of pets (cats, dogs, rabbits) with whom the children interacted and cared for. The use of sensory and perceptual-motor training was integral to children's learning and materials such as tricycles, scooters, climbing frames and slides were scattered throughout the outdoor area.

Nutrition and health were very important components in the children's experiences as the McMillans felt that children who are sick and undernourished could not learn. At lunchtime, usually between 11:30 and 12:00, children over 3 years of age were allowed to help themselves from a little serving dish passed around by a 'monitor' (another child). After the 2course lunch (main meal and dessert), the older children helped to clear the tables and set out the camp beds and blankets in the garden for the midday rest. Afternoon activities consisted of free play, music and games. Tea (afternoon meal) was served at 16:00 and school finished between 17:00 and 17:30, when the working mothers could collect their children. 
McMillan is quoted as saying:

It [the nursery] was a pleasant and a renewing world. They [the children] came back eager and wide-eyed. The camp grew lovelier and the children more resistant. There were thirty of them...ranging in age from eighteen months to seven years. In six months, from March to August, there was only one case of illness. (McMillan, 1927, p. 144)

Honor Edwards (1961), a student teacher in the nursery from 1923-1926, commented on the amount of time the nursery was open each day:

The nursery school day was a long one from 8 a.m. to 5:30 p.m. Miss McMillan stressed the urgency for this long nurture day so necessary in those days when so many children were suffering from malnutrition due to dirt, insufficient food, sleep, fresh air and play. Rickets was the most common defect, and perhaps the most satisfactory aspect of our work was our children which took place before our eyes.

In order to role model their ideals for improving the lives of the children and families in the surrounding community, the sisters had a flat on the open-air nursery grounds, becoming the neighbours of the people with and among whom they worked, operating a simple but highly effective regime for local children that could be funded through Margaret's continual canvassing for public funds or charitable donations, including from some of the wealthy visitors to the Deptford nursery like George Bernard Shaw (member of the Fabian Society) and Queen Mary. Unlike these more privileged individuals who eventually joined the campaign for nurseries, the sisters "had a little family money [and] were content to live frugally and trust to providence" (Bradburn, 1989, p. 149).

\section{The Education of Women to Teach Young Children}

Margaret McMillan was a feminist and suffragette and envisioned the nursery opening opportunities for young women to develop leadership skills 
and a career so they would gain independence, contrary to the societal trends of the turn of the last century. Additionally, McMillan's goal for teachers of young children was for them to gain insight into the theoretical and practical aspects of young children's development and learning.

The life opening now before the eyes of young womanhood is big with new powers, opportunities, interests and risks and potencies. The young are soon to be citizens. Girls of 21 will soon have the vote. They are here, then, no more to be protected, but to protect, to cherish and the whole fate and future of vast armies of human beings lies to a greater degree in the hands that yesterday were believed to be fully and righteously occupied in fine embroidery and the practice of scales. (McMillan, 1927, p. 200-201)

McMillan believed in the capabilities of women and strived to empower them to pursue a career rather than stick to a mindless, dead-end job by educating them to care for and teach young children. The Froebelian construct of teaching which mirrors motherhood "draws on generalised social perceptions of fit work for women" (Steedman,1988, p.87) and McMillan sought to draw on these ideals while simultaneously empowering young women to become leaders and develop marketable skills in order to gain independence in their work and financially in their personal lives.

Margaret's experience with the teachers she encountered made her realise the urgent need for specific training for those who intended to work with the disadvantaged pre- school children. Consequently she decided to initiate courses for teachers and to use the Nursery School as an integral part of their training. (Bradburn, 1989, p.183)

Margaret McMillan wrote:

In 1919 there were very few Nursery Schools of any kind, and no large open-air Nursery School that I know of other than our own. As for the training of teachers it was not even considered as yet, so confused, so blind indeed was the general view on this. Many people believed that training of any kind was unnecessary for a nursery teacher, just as they still believe that it is quite unnecessary for the woman who is a mother. Nursery Schools were to be a dumping- 
ground for the well-intentioned but dull women of that day. (McMillan, 1919, p. 4)

Practice preceded academic work and the study of educational theorystudent teachers had one year of practice before educational study. Margaret felt that once the student teachers understood the nature of children and their learning from observing and interacting with them, they would then be ready to engage in academic study. Student teachers were sent into the community for home visit of the young children enrolled in the nursery as their first experience working with children and families. Margaret felt that these future teachers needed to understand from the children came before being able to understand how to support their learning in the nursery. Many of the student teachers, who were young, middle-class women hoping to make a difference to society through their teaching, were quite astonished by the level of poverty in which the families lived and had to quickly adjust to the needs of the children and families.

At the time, a two-year programme was typical for early years teacher education and McMillan was adamant that future early years teachers needed no less than a three year programme to be fully trained to teach young children. The Rachel McMillan Teacher Training College did not have a physical building in which to educate teachers until 8 May, 1930. Teacher training up until that point took place in the nursery. Training at the Deptford Centre was offered as early as 1914, though it was not recognised by the Board of Education until 1919, when grants for a one-year residency in Deptford (on top of students' two-year training in other colleges) were made available (McMillan, 1919, pp. 19-20). All applicants were interviewed by Margaret McMillan and their three years of education were carefully monitored by her.

Porter (1961), a student with McMillan from 1917-1920 remembers her interview:

...she [McMillan] described to me the ideal type of students she wanted to have at her Training Centre, and what she would like them to be taught - she said that she had tried nurses, and teachers, but that neither had just what was needed for Nursery School work, and she had decided that a new type of training was required and that it should be started at the Rachel McMillan Training Centre at 


\section{HSE - Social and Education History, 7(1) 93}

Deptford. At the end of the interview Miss McMillan said that she considered me a suitable applicant, and she hoped that I would decide to take the training.

According to a former student "There was a strong spirit of dedication among students constantly reinforced by the example of Margaret McMillan. The daily living conditions were hard and somewhat bleak" (Edwards, 1961). She goes on to say that the teacher education she received was quite rigorous and very specific:

We worked in the Nursery or Camp School for part of each day under the guidance of skilled teachers. Lecture were so organised as to fit in with our practical work with the children and these were given in small rooms in the four hotels [where student teachers lived].

The curriculum organised by McMillan included a balance of carefully considered foci and the three-year programme provided study in Principles, Practice and History of Education; Health and Physical Education; Needs and interests of children in relation to the Nursery, Infant and Junior school ages; Spoken and Written English. The first year of study included: Music, Bookcraft, Handiwork, Needlework, Art, Pottery, Environmental studies, Weaving, English Language and Literature, History, Divinity and Biology. In the second year, a specialisation was chosen and visits for observations made at different types of schools including special schools; Health Centres and Clinics; Museums, Galleries, and Exhibitions. While in the third year, observations and lectures continued and there were examinations at the end of this year to include: Theory of Education, General and Special including Health Education; Class Teaching; Physical Education; and Specialist Subject. Much of these foci are still included in contemporary early years teacher education. McMillan had a vision of appropriately trained staff who were confident and able to support children and their families teaching in open-air nurseries all over England (Giardiello, 2014).

Margaret had a great deal of respect for the mothers she worked with and provided opportunities for them to meet together for social, educational and cultural events - the latter even including lectures by figures such as Walter de la Mare and George Bernard Shaw. She had an intuitive belief that 
parents are children's first and most important educators and recognised that they had an important part to play in the running of the nursery.

Margaret realised that it was only through education that the working class, repressed and depressed, could become strong enough to stand alongside the privileged and her experience of being a school governor had shown her the value of a teacher. Certain aspects of her experience of working with the rich was absorbed into practice in her nursery school - the practice of the teacher sitting alongside the children at mealtimes being an echo of the more genteel experience she was familiar from her time as a governess.

Margaret also had a concern for parents and she firmly believed that parental involvement was pivotal to the educational process and teachers were charged with getting to know the parents as well as the children, with the teacher taking on many of the roles assumed by the many adults supporting a mother in a more affluent home. She intuitively believed that most parents want what is best for their children and explored strategies for helping parents become aware of their own effectiveness. Her attitude to parents was informed by research in Germany and she was never patronising towards them - quite unusual in a society that was paternalistic towards the poor (and women).

\section{Conclusion}

This investigation focused on early twentieth century Christian Socialist reformer Margaret McMillan as a 'liberatory pedagogue', focusing on her work with disadvantaged children and their families in the nursery that she established in 1914 in Deptford, South London. She remarked to a group of her children 'you may be poor now, but there is nothing to stop you sitting in the Houses of Parliament one day' and this investigation explores how she worked tirelessly to make this a reality. The paper drew on archival data collected by the author relating to feedback given by the children and student teachers with whom she worked.

McMillan's Christian Socialist ethos led to her primarily focusing on the early years setting as a remedy for social disadvantage - for the children, the families and the community. McMillan's respectful practice with children from economically deprived backgrounds and their families pioneered a practice which still influences early childhood practice in the UK and the 
United States. This exploration delves into how she set up to 'plan the right kind of environment for (children) and give them sunshine, fresh air and good food before they become rickety and diseased'.

Mansbridge sums up Margaret's work and influence:

She heard the call to work, she schemed, and planned and she succeeded. There is a universal testimony, educational literature abounds with it, to the power of her redemptive action. Little children made straight, bounding into life, with bright eyes, attuned ears, sensitive touch and high spirits. The working mothers of Deptford, as they tell it, seem to be transformed; they speak of Margaret as one who did so much that she is, in the spirit still with them. The little children of the Nursery school returned to their homes as new creatures, inviting new conditions of feeding and treatment. All about them their elder sisters come from far, learn the magic and mystery of childhood, and go out to take other gardens in the midst of the slums. (Mansbridge, 1932, pp. 82-83)

\section{References}

Bradburn, E. (1989). Margaret McMillan: Portrait of a Pioneer. London: Routledge.

Brain, R. (1961) Margaret McMillan: reflection. [Letter].Dreadnought Library (A8/16, Box 1). University of Greenwich, Greenwich, London, UK. Letter written about nursery experiences

Cresswell, D. (1948). Margaret McMillan: a memoir. London: Hutchinson and Company, Ltd.

Edwards, H. (1961). Margaret McMillan Training College. [Letter].Dreadnought Library (A8/18, Box 1). University of Greenwich, Greenwich, London, UK. Letter written about nursery experiences

Franklin, G. (2009). Inner-London Schools 1918-44: A Thematic Study. Research Department Report Series no. 43-2009.

Giardiello, P. (2014). Pioneers in Early Childhood Education: The roots and legacies of Rachel and Margaret McMillan, Maria Montessori and Susan Isaacs. London: Routledge. 
Lob, D. (1961). Margaret McMillan: reflection. [Letter]. Dreadnought Library (A8/24, Box 1). University of Greenwich, Greenwich, London, UK. Letter written about teacher education in the nursery

Mansbridge, A. (1932). Margaret McMillan Prophet and Pioneer. London: Dent.

McMillan Legacy Group (1999). The Children Can't Wait: The McMillan Sisters and the Birth of Nursery Education. London: Deptford Forum Publishing Ltd.

McMillan, M. (1917). The Camp School. London: George Allen and Unwin McMillan, M. (1919). The Nursery School. London: J. M. Dent \& Sons, Ltd. McMillan, M. (1927). The Life of Rachel McMillan. London: J. M. Dent \& Sons, Ltd.

Pease, E. R. (1916). The History of the Fabian Society. New York: E.P. Dutton \& Company

Porter, J. (1961). Margaret McMillan: reflection. [Letter]. Dreadnought Library (A8/28, Box 1). University of Greenwich, Greenwich, London, UK. Letter written about teacher education in the nursery

Puddephat, M. (1977). Margaret McMillan 1860-193: Reminiscences. Rachel McMillan College Association [Pamphlet]. [London, England].

Simon, B. (1965). Education and the Labour Movement 1870-1920. London: Lawrence and Wishart.

Steedman, C. (1990). Childhood, Culture and Class in Britain: Margaret McMillan 1860-1931. New Jersey: Rutgers University Press.

Steedman, C. (1988). Margaret McMillan. In: M. Woodhead and R. McGrath, ed., Family, School and Society. Milton Keynes: Open University Press.

Ventresca, M. J. and Mohr, J. W. (2001). Archival Research Methods. London: Blackwell Publishers.

Villaverde, L., Helyar, F. and Kincheloe, J. (2006). Historical Research in Education. In: K. Tobin and J. Kincheloe, ed., Doing Educational Research: A Handbook. Rotterdam: Sense Publisher.

Betty Liebovich: Lecturer at Educational Studies Department. Goldsmiths University of London.

Contact Address: b.liebovich@gold.ac.uk 